\title{
From Modal Particle to Interrogative Marker: A Study of German denn
}

\author{
JOSEF BAYER
}

\section{INTRODUCTION}

The German particle denn (from Old High German temporal thanne, "then," and related to Engl. then and German dann, "then") is either a conjunctive or a so-called "modal particle" (MP), also known as "discourse particle." Only the latter use will be of interest here. Denn as an MP is in its core occurrences confined to root V1-questions and V2 wh-questions. Its occurrence in clauses of that type is optional. It signals that the speaker is in a particular way concerned about the answer that his or her question will elicit. An analysis will be offered according to which denn is a functional head that heads a particle phrase that is in construction with the CP's layer of illocutionary force. The Bavarian dialect that will be in the focus of the final part of this article does not employ the lexical element denn but rather the clitic form $-n$ (which appears to be related to denn). This clitic element is interesting as it combines two remarkable properties that distinguish it from denn. The article is organized as follows: Section 1 explains the discourse function of denn. Section 2 develops the syntax of denn. Section 3 turns to the role of denn in Bavarian where it has turned into a clitic element. A conclusion is given in section 4 . 


\section{THE DISCOURSE RELEVANCE OF GERMAN DENN}

In its function as an MP, the German particle denn occurs in root questions as in (1) and (2) where it gives rise to an attitude of wondering and being concerned on the side of the speaker.

(1) Disjunctive question (V1)

Hat dich denn Dr. Schreck angerufen?

has you PRT Dr. Schreck called

'Did Dr. Schreck call you? (I am wondering)'

(2) Constituent question (V2)

Wer hat dich denn angerufen?

who has you PRT telephoned

Who called you? (I am wondering)'

MPs like denn have "expressive" rather than "descriptive" meaning. ${ }^{1}$ König (1977) Wegener (2002) and Grosz (2005) emphasize the addressee's knowledge to which denn signals a relation. According to König and Wegener, denn is inappropriate if the question opens a discourse out of the blue. ${ }^{2}$ The deeper reason for this may, however be that there is no common knowledge background to which a true answer could relate. For instance, an administration officer whose sole job is to write down a citizen's address can hardly felicitously ask Wo wohnen Sie denn? ("Where do you live, I am wondering?"). The officer is not concerned as there is no (or perhaps too weak a) common ground that could be updated by a true answer to these questions. Let me propose the pragmatic condition in (3).

(3) [denn $\alpha$ ] is appropriate in a context $c$ if (i) $a$ is a question and (ii) the expected true answer $\mathrm{p}$ updates the common knowledge $\mathrm{K}$ of speaker and addressee in such a way that $\mathrm{p}$ is relevant to the knowledge $K^{\prime}$ of the speaker.

The relevance requirement implies that the speaker is CONCERNED about the answe as it relates to his/her contextually given knowledge in a way that matters for him/ her in one way or another ${ }^{3}$ In the syntactic account of denn to follow in section 2 , will encode the anaphoric link that denn supplies a question with by means of the

1. Expressive meaning is that part of meaning which informs about the actual utterance situation (in contrast to the truth conditions). MPs fall in the domain of "expressives": cf. Kratzer (1999; 2004), Grosz (2005) and further references provided there.

2. Konig's example: A wakes up his wife and askes Wie spät ist es denn? (How late is DENN?) According to him it is inappropriate because the addressee lacks a context in which to interpret to huestion. It is appropriate if the wife asks $A$ the same que which to inteplet

3. One may object that denn may also appear in non-information-seeking interrogatives, e.g. feature [Conc] for "concern". ${ }^{4}$ (3) predicts that denn is confined to root clauses because only root clauses make indexical reference to the speaker via the highest layer of the split-CP domain that is known as the force projection. We shall see whether this prediction has to be modified or not.

The context dependency of denn which is captured in (3) agrees well with Behaghel's (1923-1928) observation - referred to by Dittmann (1980) and Wegener (2002) - that denn has an anaphoric meaning due to its origin from OHG thanne. Thanne refers to previously mentioned or situationally recovered circumstances as seen in the following example.

(4) Ther púzz ist filu diofer, war nimist thu thánne ubar thá the well is much deeper where take you then over the wazar flíazzantaaz [Otfried II, 14, 29f.]

water running

"The well is very deep, so where will you then take running water?

Although the current use of denn does in many cases not allow an anaphoric interpretation as concrete as thanne, there seems to be an abstract residue of this usage by which the speaker signals that the question is situationally anchored in what he/she takes to be the situationally given common ground.

As the contrast between (5a) and (5b) shows, denn may arise in an embedded clause with root-interpretation due to a selecting verbum dicendi but not in a propositional attitude context as in (5b).

$\begin{array}{lllllll}\text { (5) a. Christine } & \text { fragte, warum } & \text { der Klaus denn soblass ist } \\ \text { Christine } & \text { asked } & \text { why } & \text { the Klaus } & \text { PRT } & \text { so pale is } \\ \text { b. *Christine } & \text { weiß, warum } & \text { der Klaus denn so blass ist } \\ \text { Christine knows why } & \text { the Klaus PRT sopale is }\end{array}$

(i) Bist du denn wahnsinnig? are you DENN crazy

(ii) Wie siehst du denn aus? how look you DENN

What is special here is the question, however, not the contribution of denn. While the speaker implies that the addressee is crazy or looks weird he/she nevertheless expects an update implilly some expanation - which matters for his/her contextually determined knowledge

typically some exp (1989: 200) suggests a somewhat similar feature, <konnex>, to charac

4. Thurmair (1989. 200) suggests a somewhat sim lar feature, 〈konnex〉, to charac terize the dair (19 the core contribution of an individual particle. 
In (5a), the attitude of wondering/being concerned is, of course, ascribed to Christine and not to the speaker.

\section{THE SYNTAX OF DENN}

In this section it will be shown that denn precedes high discourse oriented adverbs and also occupies the highest position in the hierarchy of MPs. We will then provide arguments for the place of denn in clause structure. Finally cases will be considered in which denn, contrary to expectation, does appear in embedded clauses in the scope of a propositional attitude verb.

\subsection{Hierarchy}

Following the lead of Cinque (1999) for the ordering of adverbs, one can show that denn precedes the adverbs which figure as the highest in Cinque's hierarchy. ${ }^{6}$ For instance, schließlich (finally), zum Glück (fortunately), and schlauerweise (intelligently), dummerweise (stupidly) belong to the higher adverbs. As the following examples show, they can never precede denn.

(6) a. Bist du denn schließlich ans Ziel gekommen? are you PRT finally at-the goal come 'Did you finally reach the goal? (I am wondering)'

b. 'Bist du schließlich denn ans Ziel gekommen?

(7) a. Hat der Hans denn schlauerweise die Heizung zurückgeschaltet? has the Hans PRT cleverly the heating back-switched 'Did Hans cleverly reduce the heating? (I am wondering)'

b. 'Hat der Hans schlauerweise densn die Heizung zurückgeschaltet?

(8) a. Wer ist denn schließlich ans Ziel gekommen? who is PRT finally at-the goal come 'Who reached the goal finally? (I am wondering)'

b. "Wer ist schließlich denn ans Ziel gekommen?

(9) a. Wer hat sich denn zum Glück gemeldet? who has REF PRT to-the luck responded 'Who has luckily responded? (I am wondering)'

b. "Wer hat sich zum Glück denn gemeldet?

5. Cf. Doherty (1985: 76f.). Doherty argues that denn cannot be used in self-directed questions because it relates to the attitude of an interlocutor. I disagree with her intuition. Monological questions such as

(i) Wo habe ich denn meine Brille hingelegt?

'Where did I put my glasses (I am wondering)?'

are perfectly normal. (3) is compatible with such a case because speaker and addressee may happen to be identical.

6. For detailed discussion cf. Coniglio (2005; 2009) and Grosz (2005)
An exception to which we will turn shortly seem to be adverbs of time and space such as gestern (yesterday), heute (today), damals (in those days), hier (here), dort (there) etc.

(10) Hat mich (gestern) denn (gestern) jemand anrufen wollen? has me (yesterday) DENN (yesterday) someone call wanted 'Did someone want to call me yesterday (I am wondering)?'

As Thurmair (1989), Abraham (2000), Coniglio (2005; 2009) and Grosz (2005) show, MPs are hierarchically ordered, similarly to the order of adverbs that has been studied by Cinque. In (11) I confine myself to disjunctive questions.

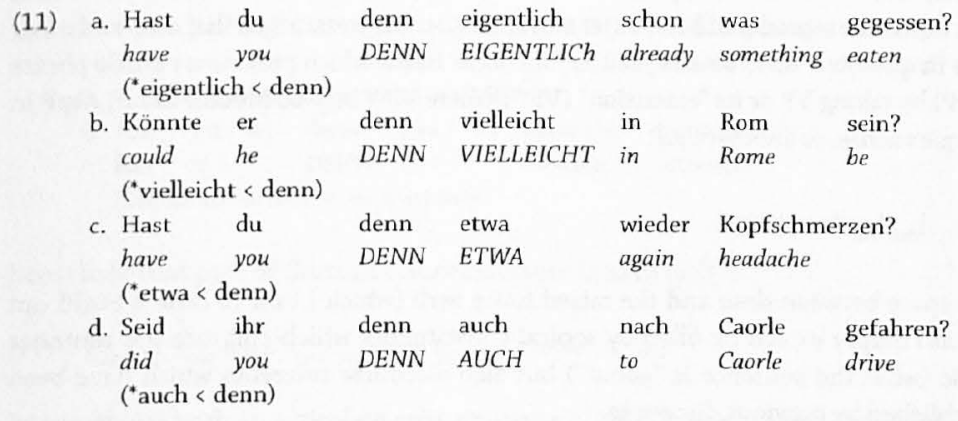

The MPs which figure in constituent questions are partially different but it is equally true that denn precedes all of them. As Coniglio (2005: 110ff.) points out, the lower MPs can precede high adverbs such as vermutlich (presumably) but can also appear in interspersed position as long as their intrinsic order is retained. With respect to denn, this yields roughly the hierarchy in (12), where we refer to the complementary class of MPs with the ad hoc feature [-denn]

(12) The position of denn in the hierarchy of MPs and adverbs $\left(\mathrm{ADV}_{\text {time/spare }}\right)>$ denn $>\mathrm{MP}_{\text {denn }}>\mathrm{ADV}>\mathrm{MP}_{\text {denn }}$

\subsection{Clause structure}

There is controversy about the X'-status of MPs to which I cannot do justice here for reasons of space. ${ }^{8}$ Tests of leftward/rightward movement, (non-) projection, coordination, focusing etc. suggest that MPs are functional heads. Various researchers nevertheless

7. Cf. Grosz (2005: 2.4.3) for further discussion. For the positioning of strong and weak pronouns, cf. section 2.2 below.

8. Cf. relevant discussions in Bayer (1991), Meibauer (1994), Coniglio (2005), Grosz (2005), Cardinaletti (2007), and Bayer and Obenauer (in press) among others. 
argue that MPs are XPs in the specifier of an empty head, albeit "degenerate" XPs. A complicating factor is that MPs do not have totally homogeneous syntactic properties. For instance, denn, unlike other MPs, can turn into a clitic (see section 3 ). It has also been argued that MPs cannot be heads because these heads would inhibit V-movement to the $\mathrm{C}^{\circ} /$ Fin $^{\circ}$-position due to the Head Movement Constraint. This argument, which applies equally to negation is, of course, theory-dependent. Empirically it appears to be problematic to deny head status to the standard negator nicht which in dialects with negative concord appears to be a head into whose specifier a negative quantifier has to move in order to check off its neg-feature. ${ }^{9}$ Negation does not interfere with V-to-C movement. It seems to be feasible to modify Relativized Minimality in such a way that the verb (or rather, its fin-feature) will skip certain medial head positions. ${ }^{10}$ On the basis of novel data that cannot be reproduced here, Bayer and Obenauer (in press) argue that denn and other MPs in questions must be analyzed as functional heads which projects a particle phrase (PrtP) by taking VP or its "extension" (VPoxt) where VPext may be MoodP, ModP, AspP in Cinque's sense, or another PrtP.

(13) $\left[_{\mathrm{PrtP}} \mathrm{I}_{\mathrm{Prt}}\right.$ denn] $\mathrm{VP}($ extr) $]$

The space between denn and the raised finite verb (which I take to head a FinP) can remain empty or can be filled by topical constituents which embrace the sentence topic (what the sentence is "about") but also discourse referents which have been established by previous discourse.

(14) a. Hat denn der Hans den Hund gefüttert?

has DENN the Hans the dog fed

'Did Hans feed the dog?'

b. Hat der Hans denn der Hans den Hund gefüttert?

c. Hat der Hans den Hund denn terHans ten Hund gefüttert?

Since adverbs of time and space, so-called "stage setting" adverbs, are potential topics, while mood-, mod-, asp-adverbs are generally not, we understand the distribution of the data in (10) and (11). ${ }^{11}$ NPs and DPs which do not qualify as topics - rhematic indefinites and quantifiers - are excluded from the topic field.

9. Cf. Bavarian

(i) Erhod I koa Schneid

he had no courage

$\mathrm{I}_{\mathrm{Neg}}$, ned teor Setmeid g'habt]]

'He was not courageous'

10. Grosz (2005) argues that German MPs must be in a spec-position in order to allow the verb to move via the empty head position. His proposal follows one of Cinque's (1999) motivations to suggest such an architecture for adverbs. The argument overlooks the important fact that in Italian the verb (in fact the participle) can land in intermediate positions while nothing of that sort can be observed in German.

11. Cf. Frey and Pittner (1998: note 35, p. 532). Cinque's (1999: 28ff.) analysis of circumstantial adverbials as predicates of VP-meanings is compatible with this view because predicates can be topics.

[18] On the Cartography of Functional Structure
(15) a. Hat denn in Venedig fjeder

has DENN in Venice everybody

/ keiner ] einen Hund?

'Does \{everybody/nobody\} in Venice have a dog?

b. *Hat \{jeder / keiner\} denn in Venedig (jeder / keiner\} einen Hund?

Indefinites which move higher than denn have a generic interpretation, in agreement with Diesing (1992), and then constitute potential topics. Pronouns can hardly remain to the right of denn. When they do they are normally accented, i.e. strong. While accented strong pronouns may appear to the left of denn as contrastive topics, weak and clitic pronouns as seen in (16b) must move up.

(16) a. Hat [mich/MICH $\}$ denn \{??mich/MICH $\}$ jemand sprechen wollen? has me DENN me someonespeak wanted 'Did someone want to talk to me/ME?'

b. Hat \{es/'s\} denn $\left\{{ }^{*} e s /{ }^{*} \mathrm{~s}\right\}$ jemanden interessiert? has it DENN it sameone interested 'Did someone take an interest in it?'

I conclude that part of German clause structure is as in (17). ${ }^{17}$

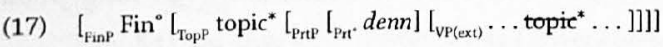

In agreement with an articulate split structure of the $\mathrm{CP}$, one can see PrtP as part of the CP-layer as suggested by one of the reviewers. Given that denn is lower than the Fin-head which activates illocutionary force, and lower than the clause-internal topic domain, this still leaves the question how to associate the particle's feature [Conc] with Fin $\%$ Force ${ }^{\circ}{ }^{13}$

Assume that denn has an unvalued interrogative feature which is valued by the finite verb in Fin $\%$ Force via a probe/goal relation as proposed in Chomsky (2001) and subsequent work. Let us attribute to MPs in questions the general feature [QForce]. [QForce] is an unvalued uninterpretable feature which is valued by [iQForce]. Ignoring for the moment the complication that emerges from dependent clauses like (5a), [iQForce] is associated with the force/fin-head of a root question.

12. One reviewer suspects that clitic and weak pronouns cannot be topics because they cannot freely move to SpecFinP (the "Vorfeld"). In my view, these constraints (where they hold) are still compatible with pronouns/clitics first scrambling into the TopP of (17) and then attaching to Fin. Relevant discussion can be found in Frey (2006).

13. The idea that $V$-fin raising triggers force goes back to Wechsler's (1991) analysis of $\mathrm{V} 2$ in Swedish and the development of his idea for German in Bayer (2004), Brandner (2004) and Truckenbrodt $(2004 ; 2006)$. Force is activated by V-raising to Fin ${ }^{\circ}$ but in an underspecified form. The distinction of declarative, imperative, interrogative mood (with the formal distinction between disjunctive and wh-questions) etc. is a matter of further tuning the elementary distinctions which may be achieved via spechead configurations 
The particle denn introduces next to [ $u$ QForce] the lexical feature [iConc]. Consider the simplest case (18) in which the force head probes denn. ${ }^{14}$

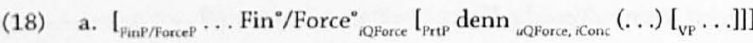

$$
\begin{aligned}
& \text { AGREE }
\end{aligned}
$$

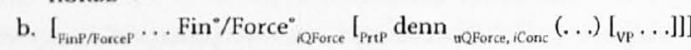

Although [Conc] enters a chain headed by [Force], it is not moved to [Force] as has been suggested in previous accounts. ${ }^{15}$ As argued in Bayer and Obenauer (in press), a pre-VP MP does not change its surface scope in the course of the derivation. The MP becomes part of the left clausal periphery by virtue of being in a probe goal relation with [Force]. The mechanism does not move the particle. We will see in section 5 that such movement would yield an undesirable result.

\subsection{Distant denn}

We have so far assumed that denn appears exclusively in the root clause or in dependent quasi root clauses as in (5a). As the following data from the internet (to which structural information about wh-extraction has been added) show, this assumption must be modified.

(19) a. Wie denkst du, dass es denn wie weitergehen soll mit euch? how think you that it DENN go-on should with you
'How do you think that the two of you should carry on? (I'm wondering)' (http://mein-kummerkasten.de/142829/fremdgehen.html)

b. Welches Bild glaubst du dass er denn wetches Bitd von mir

which picture believe you that he DENN of me

haben könnte?

have could

'Which picture do you believe that he could have of me?' (http://www.marsvenus. de/search.php?search_author=Lolaandsid=0fe369faf60ccfd8c76eee167638b51f

As the following equally grammatical examples show, neither depth of embedding nor the exact placement of denn seems to play a role as long as cyclic wh-movement passes denn.

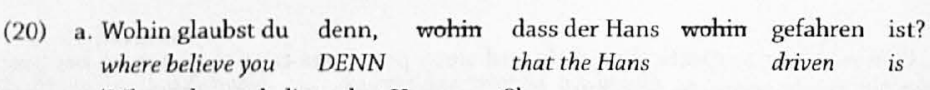
'Where do you believe that Hans went?'

14. Unlike in standard minimalism, it is not assumed here that the uninterpretable feature is exclusively associated with the probe. For details about the feature matching account behind this proposal see Pesetsky and Torrego (2007) and the use of their system in Bayer and Obenauer (in press).

15. In his description of the German MP wohl ('well') Zimmermann (2004; 2008) proposed that the MP moves to the left periphery at LF. See also a previous version of the current chapter that was temporarily available on LingBuzz.

[20] On the Cartography of Functional Structure b. Wohin glaubst du, wohin dass der Hans denn wohin gefahren ist?

c. Wohin glaubst du, wohin dass Paula meint, wohin dass der Hans

where believe you that Paula thinks that the Hans

denn wohir gefahren ist?

DENN driven is

Where do you believe that Paula thinks that Hans went?'

d. Wohin glaubst du, wohnir dass Paula denn meint, wohnin dass der Hans wohnin gefahren ist?

Putting aside embedded interrogative clauses with quasi root properties such as (5a) denn is illicit in clauses from which the wh-phrase cannot have been raised. ${ }^{16}$ The following examples show that denn cannot raise from islands.

(21) Relative-clause Island

Wer kennt (denn) eine nette Frau, die dem Hans ('denn) helfen könnte? who knows DENN a nice lady who the Hans DENN help could

'Who knows a nice lady who could help Hans?'

(22) Adjunct-Island

Warum ist (denn) der Hans, ohne (*denn) einen Führerschein zu haben why is DENN the Hans without DENN a driver'slicense to have Auto gefahren?

car driven

'Why did Hans drive a car without having a driver's license?'

(23) Complex-NP-Constraint

Wer hat (denn) die Behauptung, dass Hans (*denn) bankrott sei, aufgestellt? who has DENN the statement that Hans DENN bankrupt be made 'Who made the statement that Hans was bankrupt?

One could argue that due to subjacency denn cannot undergo classical LF-style raising. However, dependent clauses from which movement is potentially possible are equally out as long as no wh-phrase passes through the minimal clause which hosts denn.

(24) a. Wer hat dir (denn) erzählt, dass der Hans (*denn) weggefahren ist? who has you DENN told that the Hans DENN left 'Who told you that Hans has left?'

b. Habe ich dir (denn) schon erzählt, dass der Hans (*denn) have I you DENN already told that the Hans DENN weggefahren ist?

'Did I tell you already that Hans has left?'

16. To be precise, it is not wh-movement as such but rather the general class of mechanisms by which the scope of the embedded clause can be extended to the root clause. The following example of partial movement yielded perfect acceptability in a judgment test with 20 speakers.

(i) Was glaubst du, wohin der Hans denn gefahren ist? what believe you where the Hans DENN driven is 'Where do you believe that Hans went?' 
Denn may physically remain in a domain lower than the one in which it can be interpreted by virtue of a wh-phrase that links its feature [Conc] to the force projection. ${ }^{17}$ Denn must enter a local agree relation with the $C$-head associated with the wh-phrase. This $C$ may be [iQForce] as in ( $5 \mathrm{a}$ ) but it may also be [ $u$ QForce] as in the examples above in which the dependent clause containing denn is in the scope of a verb that does not tolerate an interrogative complement. In the latter case, the features of denn, [uQForce, iConc], undergo partial agreement with the C-head's feature [uQForce $]{ }^{18}$ As a result, the MPs uninterpretable feature is valued. This process can continue until it is terminated by [iQForce], which is normally associated with the head Fin /Force". The derivation runs as shown in (25).

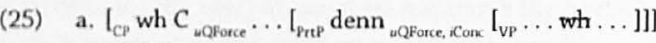

AGREB 5

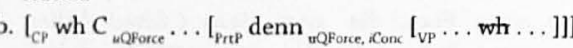

MERGE and MOVE- $V$,

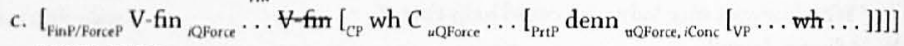

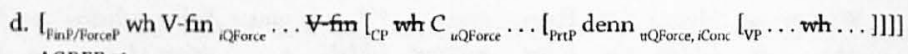
AGREB $\Rightarrow$

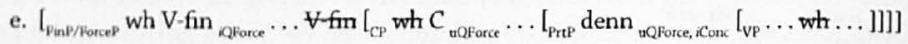

Thanks to its question-sensitive feature [uQForce $]$ and cyclic wh-movement, the particle denn is able to contribute pragmatically to the illocutionary force of the utterance "long distance". Cases like (20d) - Wohinglaubst du, dass Paula denn meint, dass der Hans gefahren ist? - follow because wh can so to say "pick up" the feature [Conc] on its way in passing the particle with which it undergoes partial agreement. Although denn does not raise to the matrix Fin/Force, the effect is that Fin/Force associates with it at a distance. As a result, denn contributes compositionally to the interrogative force of the matrix clause.

Although there is not enough space here to extend the range of related data, it should be noticed that German offers a more marked construction in which whmovement pied-pipes the MP along. Given that German obeys the V2-constraint, denn in (26) must have formed a constituent with the focalized wh-phrase wohin which moves it outwards "piggyback". ${ }^{19}$

26) [WOHIN denn] glaubst du, dass der Hans gefahren ist? where DENN believe you that the Hans driven has

There are good reasons not to derive such cases from the base seen in (17) in which MP takes a pre-VP scope position. Nevertheless, (26) provides an intuitive insight in the association of wh with MP.

17. An interesting earlier proposal in this direction can be found in Hasegawa's (1999) work on exclamatives.

18. While this is impossible in standard minimalist accounts, it is possible in the feature matching account which is assumed here following Pesetsky and Torrego (2007).

19. For detailed discussion and an account of this alternative derivation cf. Bayer and Obenauer (in press).

[22] On the Cartography of Functional Structure
As already said in note 16 , the question sensitive MP can also remain distant from the root clause in partial movement constructions as seen in (27).

(27) Was glaubst du, wohin der Hans denn gefahren ist? what believe you where the Hans DENN driven has 'Where do you believe that Hans went?'

Probe/goal agreement in the lower CP-phase works as in (25a,b). The difference is that the lower wh-phrase does not move on but is in an agreement/valuation relation with the neutral wh-element was. A natural extension of the movement analysis in (25) would be to say that was deletes the feature [uQForce] of the embedded CP but leaves the feature [iConc] of denn intact so as to make it contribute to the illocutionary force of the root clause.

After this sketch of the syntax of the German MP denn, let us in the final part consider its role in the Bavarian dialect.

\section{ENN IN BAVARIAN}

In the Bavarian variety to be discussed now, denn does not exist as a full form, but i exists as the enclitic element $-n{ }^{20}$ Bavarian is a language with Wackernagel-style cliticization to Fin or $\mathrm{C}^{\circ}$. In agreement with our analysis of Standard German in (17) topical pronouns cliticized to $\mathrm{Fin}^{\circ} / \mathrm{C}^{\circ}$ before $-n$ cliticizes to the clitic complex.

(28) Wann hod -a - s-da-n zoagt?

when has-he-it-you-N shown

"When did he show it to you?"

In spite of acceptable phonotactics, permutations as in *Wann hod-a-s-n-da zoagt?, "Wann hot-a-n-s-da zoagt? etc. are ungrammatical. $N$-cliticization turns the particle into part of the Fin/Force-head. The wh-phrase that moves to its specifier can therefore be argued to appear in a spec-head configuration with the particle. The distant placement of denn that was discussed in 2.3 is absent in Bavarian; - $n$ can target only Fin/Force. However $-n$ is at variance with denn also in two other respects: (A) it is OBLIGATORY in wh-questions. Weiß (2002) provides the following example.

(29) Wos hosd' *(-n) g'sogd?

What have-you $-N$ said

'What did you say?'

20. The dialect to be described here is my own, spoken in Dietfurt/Altmühl, a Middle to . The speakers linguists from more eastern varietios Nore judgements I had access to - Hans Altmann, Agnes Kolmer and Helmut Weiß whose judgements 
(B) it does NOT YIELD THE CONCERN INTERPRETATION. (29) is a neutral wh-question. In order to express the concern interpretation, the variant of Bavarian which is in focus here uses the non-clitic element nou or no, derived from nach(her) ("after", "after all", "then") which corresponds to Standard German denn. According to my intuitions, this element competes with $-n$, as can be seen in the following examples where we use the contracted form homna- $n$ which unambiguously involves $-n$ and thus circumvents the phonetic problem of misanalysis due to homophonous nasal segments. ${ }^{21}$

$$
\begin{aligned}
& \text { (30) a. Wou hom nou däi g'wohnt? } \\
& \text { where have NOU they lived } \\
& \text { 'Where did they live ( } 1 \text { am wondering)?' } \\
& \text { b. 'Wou homna-n nou däi g'wohnt? } \\
& \text { where have- } N \text { NOU they lived }
\end{aligned}
$$

Assume that like Standard German denn, no( $u$ ) has an unvalued feature [ $u$ QForce] as well as the feature [iConc]. The clitic $-n$ lacks $[i$ Conc]. Arguably it has only [ $u$ QForce]. Due to its impoverished nature it has turned from an MP into a pure marker of root wh-questions; in the process of cliticization $-n$ fuses with Fin $/$ Force $^{\circ}$ and imports this unvalued feature which must be valued by a wh-phrase. ${ }^{22}$ The question is then how to account for the competition between $-n$ and $n o(u)$. By their respective feature structures seen in (31), $-n$ is the default case whereas no(u) is the special case.

(31) a. $n$ [uQForce $]$

$$
\text { b. } n o(u) \text { [uQForce], [iConc] }
$$

This situation calls for an account in terms of the Elsewhere Condition proposed in Kiparsky (1973). This condition, which was originally designed as a metric for rule application in generative phonology, says that in a situation of rule competition, a rule R1 which applies to a domain D1, D1 being a proper subset of D2, prevents the more general rule R2 from applying to D1. In our case, this means that insertion of the item which includes the feature [iConc] takes precedence because it represents the special case in comparison with insertion of the item which lacks [iConc]. We derive the contrast in (30) because merger of no( $u$ ) bleeds the use of the clitic - $n$.

Interestingly, the diachronic process that has turned $-n$ into a wh-question marker has not affected disjunctive questions. Disjunctive questions in the Bavarian variety described here allow but certainly do not require $-n$, and the semantic contribution of $-n$

21. The underlying form of 1 st/3rd person plural hom ("have") is as in Standard German haben. If $-n$ cliticizes before haben reduces to hom, haben $+n$ yields habenen due to vocalic epenthesis. Reduction, in conjunction with syllabification and onset maximization, then yields the unambiguous bisyllabic form hom.nan.

22. As pointed out in Bayer (2010), the Bavarian dialect described here allows wh-drop f the pronoun wos ("what"). The option of wh-drop is arguably related to the presence of the clitic $-n$. is directly felt: (32a) is fully acceptable although $-n$ is lacking, and (32b) is semantically distinct from (32a). ${ }^{23}$

(32) a. Hom däi aa a Haus?
have they also a house
'Do they also have a house?'
b. Homna-n däi aa a Haus?

b. Homna-n däi aa a Haus?

'Do they also have a house? (I am wondering)'

Both the full form and the clitic form have the same features, a situation which, of course, gives again rise to redundancy if both are merged, but now for the trivial reason of repetition.

(33) "Homna-n nou däi aa a Haus?

have $-N$ NOU they also a house

\section{CONCLUSION}

The preceding study of the German MP denn has revealed a number of intricate syntactic properties which suggest that the study of MPs can enhance our understanding of clause structure. MPs are part of a highly articulated functional structure which systematically contributes to the illocutionary force of an utterance. In this architecture, denn projects a particle phrase that is in an agreement relation with an interrogative Fin/Force head of German V1/V2 clauses. We have made precise under which conditions denn may enter this functional structure even if it appears in a position below the root clause. Given that the complement of a believe type verb as in (19) and (20) does not project interrogative force (and perhaps lacks force altogether), distant denn must be in an agreement relation with the root which is established as a result of cyclic wh-movement.

In Bavarian, denn appears as the clitic element $-n$ which in wh-clauses is deprived of its special MP-semantics and operates more or less like a pure wh-interrogative marker. Abraham (1991) identified in the history of German a grammaticalization path of denn as in (34).

23. Cf. Plangg (1989: 659), Poletto (2000: ch.3) and Hack (2009) on the particle pa (derived from Latin post) in Northern Italian dialects. It is fascinating to see close correspondences between Bavarian $-n$ and $p a$ in varieties of Rhetoromance. First, there is a lexical correspondence between pa ( $<$ Lat. post) and Bavarian nachher ("after"). Secondly, pa has according to Hack (2009) - become obligatory in wh-questions in Badiot, Marèo and in Gherdëina, with a concomitant loss of its original meaning. She ascribes this to a process Gherammaticalization. In Gherdëina, the grammaticalization of $p a$ is more advanced than of grammaticalialects as $p a$ is obligatory in ALL questions, i.e. also in disjunctive questions. in the know if there are any dialects of Bavarian with obligatory $-n$ in all questions. 
(34) LOCALISTIC > TEMPORAL > LOGICAL > ILLOCUTIVE / DISCOURSE FUNCTIONAL

The Bavarian data discussed in section 3 show that this grammaticalization path is prolonged due to further reduction of denn toward a pure marker of root wh-questions.

(35) LOCALISTIC > TEMPORAL > LOGICAL > ILLOCUTIVE /

DISCOURSE FUNCTIONAL > WH-AGREEMENT MARK

The concomitant cline from XP to a lexical $\mathrm{X}$, to a functional $\mathrm{X}$ and finally to a clitic element echoes a familiar diachronic process.

\section{ACKNOWLEDCMENTS}

The research presented here was carried out during my 2007/2008 sabbatical at the Università Ca' Foscari, Venice whose hospitality was extremely helpful. Parts the been presented in talks in Berlin, Brussels, Konstanz, Paris, Salzburg and Venice. I profited from discussions with Hans Altmann, Markus Bader, Ellen Brandner, Anna Cardinaletti, Guglielmo Cinque, Marco Coniglio, Franziska Hack, Agnes Kolmer, Hans-Georg Obenauer, Cecilia Poletto, Helmut Weiß, and from comments by five reviewers. None of them should be held responsible for remaining deficits. Thanks to Marco Veser for editorial help. My research was supported by a grant of the Deutsche Forschungsgemeinschaft within the Konstanz SFB 471.

\section{REFERENCES}

Abraham, Werner (1991). The grammaticalization of German modal particles. In Approaches to Grammaticalization II, E.C. Traugott and B. Heine (Eds.), 331-380. Amsterdam: Benjamins.

Abraham, Werner (2000). Modal particles in German: Word classification and legacy beyond grammaticalisation. In Approaches to the typology of word classes, P. Vogel and B. Comrie (Eds.), 321-350. Berlin: de Gruyter.

Bayer, Josef (1991). German particles in a modular grammar: Neurolinguistic evidence. In Discourse Particles, W. Abraham (Ed.), 253-302. Amsterdam: Benjamins

Bayer, Josef (2004). Decomposing the left periphery: dialectal and cross-linguistic evidence. In The Syntax and Semantics of the Left Periphery, ed. H. Lohnstein and S. Trissler, 59-95. Berlin: de Gruyter.

Bayer, Josef (2010). Wh-drop and recoverability. In Structure Preserved. Studies in Syntax for Jan Koster, J-W. Zwart and M. de Vries (Eds.), 31-39. Amsterdam: Benjamins.

Bayer, Josef, and Obenauer, Hans-Georg (In press). Discourse particles, clause structure, and question types. The Linguistic Review.

Behaghel, Otto (1923-1928). Deutsche Syntax. Eine geschichtliche Darstellung. Heidelberg:
Germanistische Bibliothek.

Brandner, Eleonore (2004). Head-movement in minimalism, and V/2 as force-marking. In The Syntax and Semantics of the Left Periphery, H. Lohnstein and S. Trissler (Eds.), 97-138. Berlin: Mouton de Gruyter.

[26] On the Cartography of Functional Structure
Cardinaletti, Anna (2007). Für eine syntaktische analyse von modalpartikeln. In Gesprochende Sprache - Partikeln, E.-M. Thüne and F. Ortu (Eds.), 89-101. Frankfurt: Pete Lang.

Chomsky, Noam (1995). The Minimalist Program. Cambridge, MA: MIT Press.

Chomsky, Noam (2001). Derivation by phase In Ken Hale: A Life in Language, M. Kenstowicz (Ed.), 1-52. Cambridge, MA: MIT Press.

Cinque, Guglielmo (1999). Adverbs and Functional Heads: A Crosslinguistic Perspective. Oxford: Oxford University Press.

Coniglio, Marco (2005). Deutsche modalpartikeln: Eine syntaktische analyse. MA thesis, Università Ca' Foscari, Venezia.

Coniglio, Marco (2009). Die Syntax der deutschen modalpartikeln: Ihre distribution und Lizenzierung in Haupt- und Nebensätzen, Ph.D. diss., Università Ca' Foscari Venezia / Humboldt-Universität zu Berlin.

Diesing, Molly (1992). Indefinites. Cambridge, MA: MIT Press.

Dittmann, Jürgen (1980). Auch und denn als Abtönungspartikeln. Zugleich ein wissenschaftsgeschichtlicher Beitrag. Zeitschrift für Germanistische Linguistik 8, 51-73.

Doherty, Monika (1985). Epistemische Bedeutung. studia grammatica xxiii, Berlin: Akademie Verlag.

Frey, Werner (2006). How to get an object-es into the German prefield. In Form, Structure and Grammar - A Festschrift Presented to Günther Grewendorf on Occasion of His 60t Birthday, P. Brandt and E. Fuss (Eds.), 159-185. Berlin: Akademie-Verlag.

Frey, Werner, and Pittner, Karin (1998). Zur Positionierung der Adverbiale im deutschen Mittelfeld. Linguistische Berichte 176: 489-534.

Grosz, Patrick (2005). Dn in Viennese German. The Syntax of a Clitic Version of the Discours Particle denn. Diplomarbeit, Universität Wien.

Hack, Franziska (2009). Syntactic Variation in Interrogatives in Romance Languages and Dialects. MA thesis, Universität Konstanz.

Hasegawa, Kei (1999). Exklamativsätze im Deutschen und im Japanischen. MA thesis, Friedrich-Schiller-Universität, Jena.

Kiparsky, Paul (1973). Elsewhere in Phonology. In A Festschrift for Morris Halle, S. Anderson and P. Kiparsky (Eds.), 93-106. New York: Holt, Rinehart and Winston.

König, Ekkehardt (1997). Modalpartikeln in Fragesätzen. In Aspekte der Modalpartikeln, H. Weydt (Ed.), 115-130. Tübingen: Niemeyer.

Kratzer, Angelika (1999). Beyond Ouch and Oops. How descriptive and expressive meaning interact. Handout (Cornell Conference on Theories of Context Dependency, 26. March 1999). http://semanticsarchive.net/Archive/WEwNGUyO/Beyond\%20 \%22Ouch\%22\%20and\%20\%220ops\%22.pdf (last access: 2. June 2010.)

Kratzer, Angelika (2004). Interpreting focus: Presupposed or expressive meanings? A comment on Geurts and van der Sandt. Theoretical Linguistics 30: 123-136.

Meibauer, Jörg (1994). Modaler Kontrast und konzeptuelle Verschiebung: Studien zur Syntax und Semantik deutscher Modalpartikeln. Tübingen: Niemeyer.

Pesetsky, David, and Torrego, Esther (2007). The syntax of valuation and the interpretability of features. In Phrasal and Clausal Architecture: Syntactic Derivation and Interpretation, ed. S. Karimi, V. Samiian and W. K. Wilkins (Eds.), 262-294. Amsterdam: Benjamins.

Plangg, Guntram A. (1989). Ladinisch/Ladino. Lexikon der Romanistischen Linguistik III, 646-667. Tübingen: Niemeyer.

Poletto, Cecilia (2000). The Higher Functional Field: Evidence from Northern Italian Dialects. Oxford: Oxford University Press.

Thurmair, Maria (1989). Modalpartikeln und ihre Kombinationen. Tübingen: Niemeyer.

Truckenbrodt, Hubert (2004). Zur Strukturbedeutung von Interrogativsätzen. Linguistische Berichte 199: 313-350.

Truckenbrodt, Hubert (2006). On the semantic motivation of syntactic verb movement to $C$ in German. Theoretical Linguistics 32: 257-306.

Wechsler, Stephen (1991). Verb second and illocutionary force. In Views on Phrase Structure, K. Leffel and D. Bouchard (Eds.), 177-191. Dordrecht: Kluwer. 

Wegener, Heide (2002). The Evolution of the German Modal Particle denn. In New Reflec
tions on Grammaticalization, I. Wischer and
Benjamins. Weiß, Helmint

Microvariation, S. Three types of negation: a case study in Bavarian. In Syntactic

Institute Electronic Publications in Linguistics.
Zimmermann, Malte (2004) Kleij (Eds.), 305-332. Meertens ische Berich (2004). Zum wohl: Diskuistics.

Zimmermann, Malte (2008) Dis.

ments in Discourse, P. Cook. W. Particles in the Left Periphery. In Dislocated EleOxford: Routledge. 